\title{
CLONING AND EXPRESSION OF AN APH(3')-III PHOSPHOTRANSFERASE FROM STAPHYLOCOCCUS AUREUS IN STREPTOMYCES LIVIDANS
}

\author{
R. Crameri and J. E. Davies \\ Biogen S.A. \\ 46, Rte des Acacias, Geneva, Switzerland \\ (Received for publication April 1, 1985)
}

\begin{abstract}
An aminoglycoside $3^{\prime}$ type III phosphotransferase derived from Staphylococcus aureus plasmid pRN1956 was cloned on the high copy number Streptomycetes vectors pIJ702 and pIJ704. Streptomyces lividans transformants carrying the hybrid plasmids show a resistance pattern towards aminoglycoside antibiotics comparable to the resistance pattern of $S$. aureus. The APH(3')-III with expanded spectrum of resistance, is a useful additional marker for gene cloning in Streptomycetes.
\end{abstract}

Aminoglycoside modifying enzymes can be detected in antibiotic-producing organisms such as Streptomycetes ${ }^{1)}$, Bacillus ${ }^{2)}$ as well as in Gram-positive and Gram-negative nonproducing organisms (for a review see DAviES and $\mathrm{SMITH}^{3}$ ); they confer resistance to the organisms by inactivation of the antibiotic. It has been demonstrated that aminoglycoside modifying enzymes from Bacillus ${ }^{2}$ and Staphylococcus aureus ${ }^{4)}$ can be efficiently cloned and expressed in Escherichia coli. The development of a cloning system for the genus Streptomyces in recent years ${ }^{5,8}$ ) provides the possibility of cloning and expressing genes from different sources in this important group of organisms. Several aminoglycoside modifying enzymes have been cloned in Streptomyces lividans ${ }^{7,8)}$ and used to construct cloning vehicles $^{\theta, 10)}$. Using these vectors the tyrosinase gene from S. antibioticus ${ }^{11}$, aminoglycoside modifying enzymes from S. fradiae $^{2)}$, S. glaucescen $^{12)}$ and genes involved in the biosynthesis of antibiotics ${ }^{13,14,24)}$ have been cloned and expressed. We report here the cloning and expression of another $\mathrm{APH}\left(3^{\prime}\right)-\mathrm{III}$ phosphotransferase, that of $S$. aureus in S. lividans, which extends the number of vector genes that can be applied.

\section{Materials and Methods}

Bacterial Strains and Plasmids

S. lividans strain $1326^{15}$ was used as host for all the transformation experiments described.

Plasmid pAT48 is pBR322 harboring a cloned neomycin-kanamycin resistance gene derived from $S$. aureus plasmid pRN1956 ${ }^{16)}$ and was used as a source for the aminoglycoside (3')-III phosphotransferase gene ${ }^{4)}$. Plasmids pIJ702 and pIJ704, derivatives of the pIJ101 multicopy plasmid ${ }^{17)}$ containing the tyrosinase gene from $S$. antibioticus in different orientations ${ }^{11)}$ were used as cloning vectors.

Culture Conditions and Transformation Procedure

For protoplast preparation spores and mycelial fragments of $S$. lividans were grown in yeast malt extract medium containing sucrose $34 \%, \mathrm{MgCl}_{2} 5 \mathrm{~mm}$ and glycine $0.5 \%$. Protoplast formation and transformations were carried out as described by THOMPson et al. ${ }^{9)}$, except that the transformed protoplasts were spread directly on regeneration medium without further washing according to KIESER et al. ${ }^{17)}$. Mycelia for cell-free extracts as well as for plasmid preparations were obtained from growth in Tryptic soya broth CMI129 (Oxoid). 
Fig. 1. Derivation of hybrid plasmids pIJ702:: APH(3')-III and pIJ704:: APH(3')-III from pAT48, pIJ702 and pIJ704 respectively.

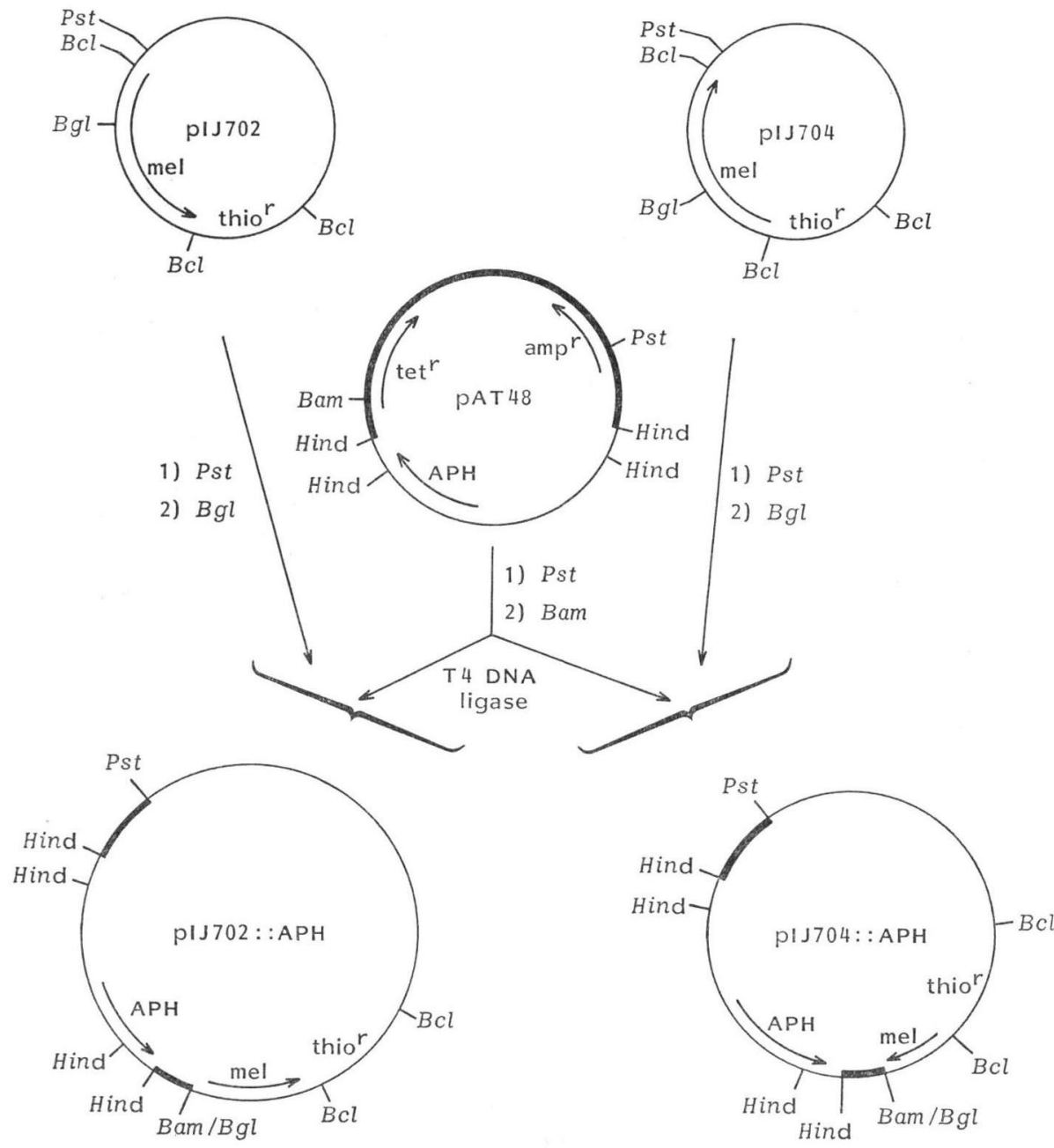

MIC (minimal inhibitory concentration) value determinations were done on yeast extract - malt extract agar ${ }^{18)}$ according to ONO et al. ${ }^{19)}$.

Detection of Transformants

Transformants were detected by the overlay method ${ }^{17)}$ using $2.5 \mathrm{ml}$ soft agar containing $200 \mu \mathrm{g} / \mathrm{ml}$ thiostrepton. Colonies containing inserts were isolated as clones unable to produce black melanin halos $^{11)}$. Direct selections were done using kanamycin at a concentration of $200 \mu \mathrm{g} / \mathrm{ml}$.

Plasmid Preparations and DNA Manipulations

Plasmids were isolated after alkaline lysis and phenol-chloroform extraction according to $\mathrm{KIESER}^{20)}$. Restriction analysis and ligations were performed according to THOMPSON et al. ${ }^{8)}$. Restriction enzymes and T4 DNA ligase were of commercial source (BRL) and used according to the suppliers recommendations. Agarose gel electrophoresis was carried out according to MANIATIS et al. ${ }^{6)}$ using Tris-acetate or Tris-borate buffer.

Preparation of Cell-free Extracts

Cell-free extracts were prepared according to BENVENISTE and DAVIES ${ }^{1)}$. 
Assay for Aminoglycoside-phosphotransferase

Cell-free extracts were first tested for the presence of modifying enzymes using a biological test. A typical inactivation reaction was prepared as follows: cell-free extract $250 \mu$, buffer containing per liter Tris- $\mathrm{HCl} \mathrm{pH} 7.4(2 \mathrm{mM}), \mathrm{MgCl}_{2}$ (0.8 mM), $\mathrm{NH}_{4} \mathrm{Cl}(0.1 \mathrm{~mm})$, dithiothreitol (0.1 $\left.\mathrm{mm}\right)$, ATP $(0.3 \mathrm{~mm})$ and antibiotic $(0.15 \mathrm{~mm}) ; 250 \mu \mathrm{l}$. The mixtures were incubated at $30^{\circ} \mathrm{C}$ for different times and the residual antibiotic activity was determined using $S$. aureus strain 209P as tester organism $^{18)}$. Radiochemical assays were carried out using the phosphocellulose paper binding method $^{11}$ with $\left[\gamma^{-32} \mathrm{P}\right]$ ATP as substrate.

Chemicals

All chemicals were of highest available purity grade from Sigma or Merck.
Fig. 2. Restriction analysis of pIJ702:: $\mathrm{APH}\left(3^{\prime}\right)$-III, pIJ704:: $\mathrm{APH}\left(3^{\prime}\right)$-III and pAT48 with Hind III, (1) $\lambda$ DNA, Eco R I+Hind III digest. (2) pIJ702:: APH(3')-III. (3) pIJ704:: APH(3')-III. (4) pAT48.

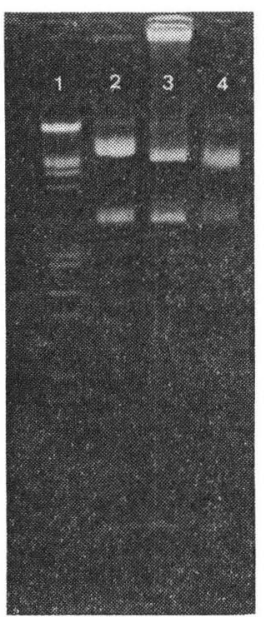

Results

Construction of Recombinant Plasmids and Detection of Transformants

The strategy used to subclone the APH( $3^{\prime}$ )-III phosphotransferase gene from plasmid pAT48 into the Streptomyces vectors pIJ702 and pIJ704 is summarized in Fig. 1. Ligation mixtures were used to transform S. lividans protoplasts. White, thiostrepton resistant colonies due to insertional inactivation of the melanin gene were isolated and plasmid mini-lysates of such strains screened for inserts. Two transformants containing plasmids of the expected size were analysed by agarose gel electrophoresis after restriction with Hind III (Fig. 2). The results confirm, that an insert containing the four expected Hind III restriction sites was present.

\section{Properties of the Transformants}

\section{Phenotypic Properties}

The MIC values of the wild type strain S. lividans, transformants containing pIJ702, and the two in vitro constructs were determined against a variety of aminoglycoside antibiotics (Table 1). The results are consistent with the broad substrate range of the $S$. aureus phosphotransferase ${ }^{4}$.

The gene dosage is apparently not sufficient to confer resistance to amikacin in vivo, but cell-free extracts of strains containing the hybrid plasmids phosphorylate this antibiotic (see later). This is probably due to the lower affinity (high $K m$ value) of the APH(3')-III for amikacin ${ }^{2,3)}$. Both recombinant constructions are very stable in $S$. lividans even after long term fermentation without selective pressure (not shown).

\section{Enzymatic Properties}

The aminoglycoside substrate profile of aminoglycoside phosphotransferase activity extracted from S. lividans transformants was determined (Table 2). The profile is consistent with that found in $S$. aureus containing pRN1956 plasmid ${ }^{\ddagger)}$. Tobramycin is, as expected, not a substrate for the phosphotransferase and the resistance levels in vivo against this antibiotic are unchanged (Table 1). 
Table 1. Minimal inhibitory concentrations $(\mu \mathrm{g} / \mathrm{ml})$ of different strains against aminoglycoside antibiotics.

\begin{tabular}{lrrrrrrrr}
\hline \multicolumn{1}{c}{ Strain } & KAN & AMI & BUT & RMS & PAR & NEO & LVDM & TOB \\
\hline Streptomyces lividans 1326 & $<4$ & $<2$ & $<5$ & 10 & 10 & $<1$ & 20 & $<5$ \\
S. lividans 1326 pIJ702 & $<4$ & $<2$ & $<5$ & 10 & 10 & $<1$ & 20 & $<5$ \\
S. lividans 1326 pIJ702:: APH(3')-III & $>150$ & $>2<5$ & 35 & $>300$ & $>50$ & $>40$ & $>60$ & $<5$ \\
S. lividans 1326 pIJ704:: APH(3')-III & $>150$ & $>2<5$ & 35 & $>300$ & $>50$ & $>40$ & $>60$ & $<5$ \\
\hline
\end{tabular}

Abbreviations: KAN kanamycin, AMI amikacin, BUT butirosin, RMS ribostamycin, PAR paromomycin, NEO neomycin, LVDM lividomycin, TOB tobramycin.

Table 2. Incorporation of $\left[\gamma_{-}^{32} \mathrm{P}\right] \mathrm{ATP}$ into different aminoglycoside antibiotics by cell-free extracts of different strains (cpm/10 $\mu$ l cell-free extract) for abbreviations see Table 1.

\begin{tabular}{|c|c|c|c|c|c|c|c|c|c|}
\hline \multirow{2}{*}{ Extract source } & \multicolumn{9}{|c|}{ Antibiotic (cpm) } \\
\hline & - & KAN & AMI & BUT & RMS & PAR & NEO & LVDM & ТОВ \\
\hline None & 167 & & & & & & & & \\
\hline Streptomyces lividans 1326 & 227 & 126 & 52 & 367 & 132 & 112 & 20 & 122 & 122 \\
\hline S. lividans 1326 pIJ702 & 141 & 92 & 50 & 287 & 161 & 89 & 34 & 134 & 134 \\
\hline $\begin{array}{l}\text { S. lividans } 1326 \\
\text { pIJ702:: APH(3')-III }\end{array}$ & 147 & 11,192 & 15,031 & 21,237 & 10,567 & 18,435 & 20,097 & 22,536 & 136 \\
\hline $\begin{array}{l}\text { S. lividans } 1326 \\
\text { pIJ704:: } \mathrm{APH}\left(3^{\prime}\right)-\mathrm{III}\end{array}$ & 162 & 18,623 & 12,521 & 28,529 & 11,610 & 29,529 & 20,545 & 24,384 & 164 \\
\hline
\end{tabular}

\section{Discussion}

The results reported here confirm that a gene for aminoglycoside antibiotic modification originally derived from the Gram-positive bacterium $S$. aureus can act as antibiotic determinant in S. lividans. The new resistance plasmids obtained by the cloning of the neomycin-kanamycin phosphotransferase from $S$. aureus into $S$. lividans confer an antibiotic resistance phenotype comparable to those due to the naturally occurring plasmid in $S$. aureus (Table 1$)^{4)}$.

The phosphorylation profile using a variety of aminoglycoside antibiotics confirms that the cloned gene corresponds to an $\mathrm{APH}\left(3^{\prime}\right)$ type III aminoglycoside phosphotransferase (lack of phosphorylation with tobramycin as substrate, but ability to phosphorylate both butirosin and lividomycin, Table 2$)^{3}$.

The fragment containing the APH( $\left.3^{\prime}\right)$-III gene was expressed in both orientations into the $B g l \mathrm{II}$ site with respect to the mel gene orientation into pIJ702 and pIJ704 (Fig. 1), therefore we can exclude expression controlled by the promotor of the melanin gene. On the other hand we cannot exclude expression coming from a vector plasmid promotor reading counter clockwise through the Pst I site (Fig. 1). The gene is in opposite orientation with respect to the tet ${ }^{\mathrm{R}}$ and $\mathrm{amp}^{\mathrm{R}}$ genes from the E. coli plasmid pBR322 and the start of the phosphotransferase coding sequence is preceded from $779 \mathrm{E}$. coli base pairs followed by 1,288 base pairs of $S$. aureus DNA ${ }^{22)}$. This could support the idea, that translational regulatory sequences from $S$. aureus are recognised by $S$. lividans. On the other hand no obvious homologies exist between the pre-gene sequence of a APH 3' phosphotransferase from $S$. fradiae and the ribosome binding site or promoter sequences found in other bacterial systems ${ }^{22,23)}$. In contrast the S. aureus APH 3' pre- and post-gene sequences contain signal sequences closely resembling to those observed for other bacterial and bacteriophage genes ${ }^{18,22)}$. Since the $S$. aureus gene has been sequenced $^{16)}$ the function of the regulatory regions can now be studied in Streptomyces.

The cloning and expression of the typical $S$. aureus $\mathrm{APH}\left(3^{\prime}\right)$-III in Streptomycetes, provides a useful, broad substrate selective marker for cloning in this species. The staphylococcal gene expresses high level resistance to a number of aminoglycoside antibiotics and since the gene has only limited nucleic acid homology with analogous Streptomycete genes ${ }^{16)}$, the APH(3')-III can be used in studies of antibiotic production in organisms containing an amplified phosphotransferase gene that is less susceptible to loss as a result of recombination between plasmid and chromosome. 


\section{References}

1) Benveniste, R. \& J. Davies: Aminoglycoside antibiotic-inactivating enzymes in Actinomycetes similar to those present in clinical isolates of antibiotic-resistant bacteria. Proc. Natl. Acad. Sci. U.S.A. 70: 2276 2280, 1973

2) Courvalin, P.; B. Weisblum \& J. Davies: Aminoglycoside-modifying enzyme of an antibiotic-producing bacterium acts as a determinant of antibiotic resistance in Escherichia coli. Proc. Natl. Acad. Sci. U.S.A. 74: $999 \sim 1003,1977$

3) Davies, J. \& D. I. Smith: Plasmid-determined resistance to antimicrobial agents. Ann. Rev. Microbiol. 32: $469 \sim 518,1978$

4) Courvalin, P. \& M. Fiandt: Aminoglycoside-modifying enzymes of Staphylococcus aureus: Expression in Escherichia coli. Gene 9: 247 269, 1980

5) Chater, K. F.; D. A. Hopwood, T. Kieser \& C. J. Thompson: Gene cloning in Streptomyces. Curr. Top. in Microbiol. \& Immun. 96: 69 95, 1982

6) Maniatis, T.; E. F. Fritsch \& J. Sambrook: Molecular cloning. Cold Spring Harbor Laboratory, Cold Spring Harbor, N.Y., 1982

7) Murakami, T.; C. Nojiri, H. Toyama, E. Hayashi, K. Katumata, H. Anzai, Y. Matsuhashi, Y. Yamada \& K. NagaoKa: Cloning of antibiotic-resistance genes in Streptomyces. J. Antibiotics 36: 1305 1311, 1983

8) Thompson, C. J.; J. M. WARD \& D. A. Hopwood: DNA cloning in Streptomyces: Resistance genes from antibiotic producing species. Nature 286: 525 527, 1980

9) Thompson, C. J.; Ward J. M. \& D. A. Hopwood: Cloning of antibiotic resistance and nutritional genes in Streptomyces. J. Bacteriol. 151: 668 677, 1982

10) Thompson, C. J.; T. Kieser, J. M. WARd \& D. A. Hopwood: Physical analysis of antibiotic resistance genes from Streptomyces and their use in vector construction. Gene 20: 51 62, 1984

11) Katz, E.; C. J. Thompson \& D. A. Hopwood: Cloning and expression of the tyrosinase gene from Streptomyces antibioticus in Streptomyces lividans. J. Gen. Microbiol. 129: 2703 2714, 1983

12) Hintermann, G.; R. Crameri, M. Vögtli \& Hütter: Streptomycin-sensitivity in Streptomyces glaucescens is due to deletions comprising the structural gene coding for a specific phosphotransferase. Mol. Gen. Genet. 196: 513 520, 1984

13) Feitelson, J. S. \& D. A. Hopwood: Cloning of a Streptomyces gene for an $O$-methyltransferase involved in antibiotic biosynthesis. Mol. Gen. Genet. 190: 394 398, 1983

14) GiL, J. A. \& D. A. Hopwood: Cloning and expression of a $p$-aminobenzoic acid synthetase gene of the candicidin producing Streptomyces griseus. Gene 25: 119 132, 1983

15) Lomovskaya, N. D.; N. M. Mkrtumian \& V. N. Danilenko: Characterization of temperate actinophage C31 isolated from Streptomyces coelicolor A3(2). J. Virol. 9: 258 262, 1972

16) Gray, S. G. \& W. M. Fitch: Evolution of antibiotic resistance genes: The DNA sequence of a kanamycin resistance gene from Staphylococcus aureus. J. Mol. Biol. \& Evol. 1: 57 66, 1983

17) Kieser, T.; D. A. Hopwood, H. M. Wright \& C. J. Thompson: pIJ101, a multi-copy broad host-range Streptomyces plasmid: Functional analysis and development of DNA cloning vectors. Mol. Gen. Genet. 185: 223 238, 1982

18) Pridham, T. G.; P. Anderson, C. Foley, L. A. Lindenfelser, C. W. Hesseltine \& R. G. Benedict: A selection of media for maintenance and taxonomic studies of Streptomyces. Antibiot. Ann. 19561957: $947 \sim 953,1957$

19) Ono, H.; R. Crameri, G. Hintermann \& R. Hütter: Hydroxystreptomycin resistance and production in Streptomyces glaucescens. J. Gen. Microbiol. 129: 529 537, 1983

20) Kieser, T.: Factors affecting the isolation of ccDNA from Streptomyces lividans and Escherichia coli. Plasmid 12: 12 19, 19 36, 1984

21) Courvalin, P. \& J. Davies: Plasmid mediated aminoglycoside phosphotransferase of broad substrate range that phosphorylates amikacin. Antimicrob. Agents Chemother. 11: 619 624, 1977

22) Gray, S. G.: Aminocyclitol resistance in Staphylococcus aureus: Analysis of the resistance enzymes and plasmids and comparison of aminocyclitol 3'-phosphotransferases. Ph. D. Thesis, Univ. WisconsinMadison, 1982

23) Thompson, C. J. \& G. S. Gray: Nucleotide sequence of a streptomycete aminoglycoside phosphotransferase and its relationship to phosphotransferases encoded by resistance plasmids. Proc. Natl. Acad. Sci. U.S.A. 80: 5190 5194, 1983

24) Martin, J. F. \& J. A. GiL: Cloning and expression of antibiotic production genes. Biotechnology 1984: 63 72, 1984 